\title{
ANALISIS PENERAPAN TIGA PILAR KEBIJAKAN PEMERINTAH DALAM PEMBINAAN PENDIDIKAN ANAK USIA DINI
}

\author{
Felix Semaun \\ Fakultas Ilmu Sosial dan Ilmu Politik Universitas Kapuas Sintang \\ Email :felixsemaun@gmail.com
}

\begin{abstract}
Abstrak
Penelitian ini bertolak dari realita kesempatan memperoleh pendidikan anak usia dini di Kabupaten Sintang masih belum merata sampai di desa-desa dan masih terkonsentrasi di daerah perkotaan, kurangnya tenaga pendidik dan kependidikan dari segi kualitas dan kuantitas. Tujuan penelitian ini adalah untuk menganalisis dan mendeskripsikan penerapan tiga pilar kebijakan pemerintah dalam pembinaan pendidikan anak usia dini di Kabupaten Sintang.Tujuan khusus penelitian adalah mengetahui 1) bentuk tiga pilar kebijakan pemerintah dalam pendidikan anak usia dini di Kabupaten Sintang,2) kendala dalam merealisasikan tiga pilar kebijakan pemerintah dalam pendidikan anak usia dini di Kabupaten Sintang, 3) upaya pemerintah dalam mewujudkan tiga pilar kebijakannya dalam pendidikan anak usia dini di Kabupaten Sintang. Jenis penelitian ini adalah deskriptif, dengan pendekatan kualitatif. Subjek penelitian ditentukan dengan teknik purposive sampling. Subjek penelitian adalah Kepala Dinas Pendidikan Kabupaten Sintang, Kepala Seksi Pendidikan Anak Usia Dini Dinas Pendidikan Kabupaten Sintang, Dewan Perwakilan Rakyat Daerah Kabupaten Sintang bagian pendidikan. Hasil penelitian menunjukkan pentingnya penerapan tiga pilar kebijakan pemerintah dalam pendidikan anak usia dini di Kabupaten Sintang agar setiap desa mendapat kesempatan pembinaan pendidikan anak usia dini dengan guru yang profesioanl dalam bidangnya.

Kata Kunci : Tiga pilar, Kebijakan Pemerintah, Pendidikan Anak Usia Dini.
\end{abstract}

\begin{abstract}
This research departs from the reality that the opportunity to obtain early childhood education in Sintang District is still not evenly distributed in the villages and is still concentrated in urban areas, lack of educators and education in terms of quality and quantity. The purpose of this study was to analyze and describe the application of three pillars of government policy in fostering early childhood education in Sintang District. The specific objective of the study was to know 1) the three pillars of government policy in early childhood education in Sintang District, 2) constraints in realizing three pillar of government policy in early childhood education in Sintang District, 3) government efforts to realize the three pillars of its policy in early childhood education in Sintang District. This type of research is descriptive, with a qualitative approach. Research subjects were determined by purposive sampling technique. The research subjects were the Head of the Sintang District Education Office, the Head of the Early Childhood Education Section of the Sintang District Education Office, the Sintang District People's Representative Council, the education department. The results of the study indicate the importance of implementing three pillars of government policy in early childhood education in Sintang District so that each village has the opportunity to foster early childhood education with professional teachers in their fields
\end{abstract}

Keywords: Three pillars, Government Policy, Early Childhood Education. 


\section{Felix Semaun}

\section{PENDAHULUAN}

Pendidikan merupakan salah satu fondasi bagi tumbuh kembang seorang anak untuk memperoleh masa depan yang lebih baik dan mencipta generasi bangsa yang dapat menghadapi persaingan global dunia. Pendidikan harus dimulai sejak dini, karena pendidikan ini dapat membentuk mental dan karakter anak di usia 0-6 tahun sebelum masuk pada jenjang Sekolah Dasar (SD). Selain itu, pada usia 0-6 tahun, anak-anak mengalami masa golden age atau masa keemasan dimana pada masa tersebut anak lebih peka untuk menerima berbagai rangsangan yang diterimanya. Salah satu pemenuhan pendidikan bagi anak usia 0-6 tahun yang dilakukan oleh pemerintah dan masyarakat adalah program pendidikan anak usia dini, Agung (2010).

Pendidikan anak usia dini (PAUD) adalah salah satu faktor penting dalam menggali sumber daya manusia yang akan berkualitas di masa depan. Pembinaan pendidikan anak usia dinidi Indonesia sejatinya dimulai dari keluarga. Keluarga adalah panti pendidikan perdana dan utama. Tanggung jawab orang tua sangat intersant dalam membentuk dan mengembangkan mental, karakter dan perilaku anak (Noorlaila, 2010: 8). Kehadiran PAUD di Indonesia telah diakui dengan adanya Undang-undang No. 20
Tahun 2003 tentang Sistem Pendidikan Nasional (Sisdiknas) yang terdapat dalam bagian tujuh, pasal 28 ayat 1-6, dimana pendidikan anak usia dini adalah suatu upaya pembinaan yang ditujukan kepada anak sejak lahir sampai dengan usia enam tahun (0-6 tahun) yang dilakukan melalui pemberian rangsangan pendidikan untuk membantu pertumbuhan dan perkembangan jasmani dan rohani agar anak memiliki kesiapan dalam memasuki pendidikan lebih lanjut. Pendidikan anak usia dini tidak hanya mencakup Taman Kanak-kanak (TK) tetapi juga Tempat Penitipan Anak (TPA), Kelompok Bermain (KB) dan lain sebagainya yang sejenis, (Depdiknas, 2007).Peran keluarga, sekolah dan lingkungan sangat besar pengaruhnya terhadap tumbuh kembang anak usia dini. Pendidik di sekolah memberikan pembelajaran dengan metode yang menyenangkan bagi anak seperti metode bermain sambil belajar, bernyanyi sambil bergerak, metode berkaryawisata di alam yang indah. Orang tua di rumah dengan cara mengasuh secara demokratis dan lingkungan yang bersih, bagus dan kondusif dengan anak menjadi stimuli moral bagi anak untuk mencintai, bersikap dan berperilaku, selain peran guru, orang tua dan lingkungan yang memotivasi anak untuk tumbuh dan 


\section{Felix Semaun}

berkembang, ada juga peran pemerintah melalui kebijakan pemerintah, (Latif dkk, 2014:27-28).

Pemerintah telah mengeluarkan tiga pilar kebijakan pemerintah yang berhubungan dengan pembinaan pendidikan anak usia dini dalam Renstra Kementrian Pendidikan Nasional 2009-2014, dan sekarang pemerintah telah menyempurnakan kebijakan-kebijakan tersebut dalam Kerangka Strategis Kementrian Pendidikan dan Kebudayaan 2014-2019.Peran Pemerintah dalam Kebijakan PAUD di Indonesia dilihat dari misi dan visi. Misi PAUD di Indonesia adalah "terwujudnya anak usia dini yang cerdas, sehat, ceria, dan berakhlak mulia serta memiliki kesiapan fisik maupun mental dalam memasuki pendidikan lebih lanjut". Sedangkan Visi PAUD adalah 1. Mengupayakan pemerataan layanan, peningkatan mutu, dan efisiensi penyelenggaraan pendidikan dini; 2 . Mengupayakan peningkatan kesadaran dan kemampuan masyarakat dalam memberikan layanan pendidikan dini; 3. Mempersiapkan anak sedini mungkin agar kelak memiliki kesiapan memasuki pendidikan lebih lanjut (Sujiono, 2013: 49).

Pemerintah mewujudkan misi dan visi PAUD di Indonesia dengan mengeluarkan Undang-Undang No.14 tahun 2005 tentang
Guru dan Dosen, dimana salah satu ketentuannya menyebutkan bahwa pendidik anak usia dini wajib memiliki kualifikasi akademik pendidikan minimum Diploma IV (D-IV) atau Strata Satu (S1) serta kompetensi sebagai pendidik. Para calon guru yang telah memiliki kualifikasi akademik S1 dan kompetensi sebagai pendidik, selanjutnya harus mengikuti uji kompetensi untuk mendapatkan sertifikat pendidik. Tujuannya supaya AUD dididik dan diajarkan oleh guru yang professional dalam bidangnya.Pada tahun 2014 juga pemerintah mengeluarkan Peraturan Menteri Pendidikan dan Kebudayaan RI No. 137 tentang Standar Nasional Pendidikan Anak Usia Dini, dan Peraturan Menteri Pendidikan dan Kebudayaan RI No. 146 tahun 2014 tentang Implementasi Kurikulum 2013 PAUD.Komitmen Indonesia terhadap PAUD tampak jelas dengan masuknya PAUD dalam Sistem pendidikan nasional. danPemerintah berupaya keras mewujudkan target tersebut sehingga meluncurkan Gerakan PAUDISASI, Satu Desa Satu PAUD, (Ditjen Dikti, 2006).

Kabupaten Sintang merupakan salah satu kabupaten di ujung timur Kalimantan Barat, memiliki semangatgerakan PAUDISASI, Satu Desa Satu PAUD. Gerakan PAUDISASI ini belum berjalan 


\section{Felix Semaun}

maksimal karena masih banyak desa yang belum memiliki PAUD disebabkan kekurangan tenaga guru dan kekurangan sarana dan prasarana. Permasalahan faktual terhadap pembinaan PAUD di Kabupaten Sintang adalah sebagai berikut; tingkat partisipasi anak usia dini (4-6 tahun) yang masih rendah, kesempatan memperoleh pendidikan anak usia dini masih belum merata di setiap desa dan terkonsentrasi di daerah perkotaan dan lebih diminati oleh masyarakat ekonomi menengah ke atas, sumber-sumber untuk pendidikan dan perawatan anak usia dini secara signifikan tidak cukup, kurangnya koordinasi pembinaan pendidikan anak usia dini antara pemerintah desa dan Dinas Pendidikan Kabupaten Sintang, kurangnya tenaga pendidik dan kependidikan dari segi jumlah dan mutu PAUD di kabupaten Sintang, (Latif, dkk. 2014: 30). Menanggapi permasalahan di atas, maka pemerintah Kabupaten Sintang menerapkan tiga pilar kebijakan pemerintah dalam pembinaan pendidikan anak usia dini.

Pilar pertama, kebijakan pemerintah dalam pembinaan PAUD adalah perluasan dan pemerataan akses PAUD. Pemerataan dan perluasan akses pendidikan diarahkan pada upaya memperluas daya tampung satuan pendidikan serta memberikan kesempatan yang sama bagi semua peserta didik dari berbagai golongan masyarakat yang berbeda baik secara sosial, ekonomi, gender, lokasi tempat tinggal dan tingkat kemampuan intelektual serta kondisi fisik. Kebijakan ini ditujukan untuk meningkatkan kapasitas penduduk Indonesia untuk dapat belajar sepanjang hayat dalam rangka peningkatan daya saing bangsa di era global, (Hanafi, 2015).

Pilar kedua, kebijakan pemerintah dalam pembinaan PAUDadalah peningkatan mutu, relevansi dan daya saing. Peningkatan mutu PAUD berkaitan erat dengan standar PAUD dituangkan dalam Peraturan Menteri Pendidikan Nasional RI : No 58 Tahun 2009 tentang Standar Pendidikan AUD, yang mencakup standar tingkat pencapaian perkembangan, standar pendidikan dan tenaga kependidikan, standar isi proses dan penilaian, serta standar sarana dan prasarana pengelolaan dan pembiayaan, sedangkan untuk nonformal pemerintah telah mengeluarkan kebijakan tentang Menu Pembelajaran Generik PAUD. Kebijakankebijakan tersebut dapat terlaksana dengan baik apabila disosialisasikan kepada berbagai pihak secara profesional, serta adanya hubungan dan kerjasama yang harmonis antara pemerintah pusat dan pemerintah daerah, dalam hal ini pemerintah 


\section{Felix Semaun}

daerah juga dapat mengeluarkan kebijakan dalam pengaturan penerimaan peserta didik dan penyelenggaraan pendidikan. Peningkatan mutu, relevansi, dan daya saing di masa depan diharapkan dapat memberikan dampak bagi perwujudan eksistensi manusia dan interaksinya sehingga dapat hidup bersama dalam keragaman sosial dan budaya, (Istiqomah, 2016).

Pilar ketiga kebijakan pemerintah dalam pembinaan PAUD adalah penguatan tata kelola, akuntabilitas, dan citra publik. Kebijakan tata kelola dan akuntabilitas meliputi sistem pembiayaan berbasis kinerja baik di tingkat satuan pendidikan maupun pemerintah daerah, dan manajemen berbasis sekolah (MBS), untuk membantu pemerintah pusat dan pemerintah daerah dalam mengalokasikan sumberdaya serta memonitor kinerja pendidikan secara keseluruhan. Di samping itu, peran serta masyarakat dalam perencanaan, pengelolaan, dan pengawasan kinerja pendidikan ditingkatkan melalui peran komite sekolah/satuan pendidikan dan dewan pendidikan, (Fadli, 2018).

Pentingnya penerapan tiga pilar kebijakan pemerintah dalam pembinaan PAUD berdasarkan realita permasalahan empiris di Kabupaten Sintang adalah supaya merata kesempatan memperoleh pendidikan anak usia dini di setiap desadi Kabupaten Sintang, menghadirkan tenaga pendidik dan kependidikan dari segi kualitas dan kuantitas, Pemerintah Kabupaten Sintang melalui dinas pendidikannya mesepons tentang pentingnya pembinaan pendidikan anak usia dini di setiap desa melalui persiapan sarana dan prasarana, persiapan guru yang professional dalam bidangnya. Pemerintah respons terhadap laporan beberapa badan dunia tentang rendahnya kualitas pendidikan Indonesia karena tidak dididik sejak dini.

Peneliti dalam penelitian ini,memfokuskan bagaimana penerapan tiga pilar kebijakan pemerintah dalam pembinaan PAUDdi Kabupaten Sintang. Penelitian ini bertujuan untuk menjawab pertanyaan berikut : 1) seperti apa bentuk tiga pilar kebijakan pemerintah dalam pembinaan PAUD di Kabupaten Sintang, 2) Apa saja kendala dalam melaksanakan tiga pilar kebijakan pemerintah dalam pembinaan PAUD di Kabupaten Sintang, 3) Upaya apa saja yang dilakukan dalam mengatasi kendala pelaksanaan tiga pilar kebijakan pemerintah dalam pembinaan PAUD di Kabupaten Sintang. Penelitian ini diharapkan secara teoritis, bermanfaat sebagai khazanah ilmu pengetahuan bagi pemerhati pendidikan 


\section{Felix Semaun}

anak usia dini, pemerintah melalui Dinas Pendidikan Kabupaten Sintang, para guru PAUD dan masyarakat umum. Secara praktisnya penelitian ini bermanfaat antara lain : 1) Pemerintah Kabupaten Sintang semakin giat dalam melaksanakan program yang terstruktur dalam penerapan tiga pilar kebijakan pembinaan PAUD, 2) Meningkatnya partisipasi setiap desa untuk mendirikan lembaga pembinaan PAUD, 3) Masyarakat memiliki paradigma berpikir positif tentang pentingnya pembinaan PAUD di setiap keluarga dan setiap desa di Kabupaten Sintang.

\section{METODE PENELITIAN}

Pendekatan Penelitian

Pendekatan dalam penelitian ini adalah kualitatif (qualitative approach), dengan jenis penelitian adalah deskriptif. Metode yang digunakan dalam penelitian adalah deskriptif analisis. Peneliti menggunakan pendekatan kualitatif karena hanya menganalisis dan mendeskripsikan tiga pilar kebijakan pemerintah dalam pembinaan pendidikan anak usia dini di Kabupaten Sintang

Subyek dan Lokasi Penelitian

Subyek dalam penelitian ini adalah segala sesuatu yang berkaitan dengan penerapan tiga pilar kebijakan pemerintah dalam pembinaan pendidikan anak usia dini di
Kabupaten Sintang. Subyek penelitian ditentukan dengan teknik purposive bersifat Snowball sampling artinya peneliti menentukan sendiri sampel yang diambil karena pertimbangan tertentu, (Sugiyono, 2012 : 89). Adapun yang menjadi subyek dalam penelitian ini adalah Kepala Dinas Pendidikan Kabupaten Sintang, Kepala Seksi Pendidikan Anak Usia Dini Dinas Pendidikan Kabupaten Sintang, Dewan Perwakilan Rakyat Daerah Kabupaten Sintang bagian pendidikan. Lokasi penelitian adalah Kantor Dinas Pendidikan Kabupaten Sintang. Alasan pemilihan lokasi ini adalah pertama alasan metodologis yaitu tersedianya data dan informasi yang dapat mendukung pelaksanaan penelitian mengenai tiga pilar kebijakan pemerintah dalam pembinaan pendidikan anak usia dini di Kabupaten Sintang. Kedua, alasan praktis yaitu pemerintah melalui Kepala Dinas Pendidikan Kabupaten Sintang memiliki tanggungjawab moral dalam pembinaan pendidikan anak usia dini di Kabupaten Sintang

Tahapan Pengumpulan Data

Tahapan pengumpulan data terdiri dari 3 tahap yakni tahap perencanaan, tahap pelaksanaan dan tahap analisis data. Tahap perencanaan dimulai dari mengurus perijinan dan administrasi terkait dengan 


\section{Felix Semaun}

rencana pelaksanaan penelitian. Pelaksanaan penelitian dimulai dengan menyusun instrumen penelitian berupa panduan observasi, panduan wawancara, dan dokumentasi. Pada tahap pengumpulan data peneliti terjun ke kantor dinas pendidikan untuk melakukan observasi,wawancara mendalam dan dokumentasi kepada responden terkait dengan tiga pilar kebijakan pemerintah dalam pembinaan pendidikan anak usia dini di Kabupaten Sintang. Tahap selanjutnya yakni tahap analisis data, setelah selesai proses pengumpulan data diperoleh sejumlah data kualitatif. Analisis dan pengolahan data berpedoman pada data yang terkumpul dari pertanyaan penelitian. Data kualitatif dari penelitian ini yaitu hasil pengamatan dan wawancara. Data yang terkumpul dianalisis secara deskriptif.

Teknik dan Analisis Data

Pada tahapan analisis data, penelitian kualitatif bersifat induktif, bahwa semua kesimpulan dibentuk dari semua informan yang diperoleh dari lapangan. Teknik analisis data yang digunakan adalah teknik analisis data deskriptif kualitatif memanfaatkan persentase hanya merupakan langkah awal dari proses analisis data (Arikunto, 2009 : 90). Dalam proses selanjutnya analisis data kualitatif terdiri dari empat alur kegiatan yang terjadi secara bersamaan, yaitu catatan lapangan, pengumpulan informasi, penyajian informasi, dan penarikan kesimpulan, Miles dan Huberman, dalam (Sugiyono, 2014 : 138). Analisis data dilakukan secara deskriptif (descriptive analysis). Berkaitan dengan validitas data, peneliti merujuk pada pendapat Nasution (2009 : 114), cara yang dapat dilakukan dalam mengusahakan agar kebenaran hasil penelitian dapat dipercaya, diantaranya: (a) memperpanjang masa observasi, (b) pengamatan secara terus menerus, (c) triangulasi, (d) menggunakan bahan referensi, dan (e) melakukan member check. Hasil analisis data disajikan dalam bentuk laporan penelitian.

\section{HASIL DAN PEMBAHASAN}

Bentuk tiga pilar kebijakan pemerintah dalam pembinaan PAUD di Kabupaten Sintang.

Bentuk penerapan tiga pilar kebijakan pemerintah dalam pendidikan anak usia dini di Kabupaten Sintang adalah menurut Kepala Dinas Pendidikan Kabupaten Sintang mengatakan adanya perluasan dan pemerataan akses pendidikan anak usia dini di setiap desa. Kepala desa sebagai pimpinan masyarakat desa diharapkan menyiapkan lahan atau lokasi pendirian 


\section{Felix Semaun}

pembinaan PAUD dan memotivasi masyarakat desa agar anak-anak usia 4-6 tahun wajib mengikuti PAUD. Kabupaten Sintang memiliki pembinaan PAUD yang masih kurang karena dukungan dari desa dan masyarakat desa yang tidak kondusif.

Menurut Kepala Seksi Pendidikan Anak Usia Dini Dinas Pendidikan Kabupaten Sintang mengatakan salah satu bentuk tiga pilar kebijakan pemerintah dalam pembinaan PAUD adalah penguatan tata kelolah, akuntabilitas dan citra publik. Selama ini pembinaan PAUD masih konsentrasi di kota-kota. Sarana-prasarana pun terfokus pada PAUD di kota. Sementara di setiap desa belum maksimal karena kekurangan sarana-prasarana, kekurangan guru bahkan ketiadaan guru yang profesional dalam bidang PAUD. Saat ini rata-rata guru PAUD di desa-desa hanya tamatan SMA dan Sarjana Pendidikan yang bukan berbasis Pendidikan Guru-PAUD. Kekurangan guru yang berkualitas inilah yang membuat masyarakat desa kurang maksimal mendukung anaknya untuk mengikuti pembinaan PAUD. Penguatan tata kelolah meliputi anggaran dalam meningkatkan sarana dan prasarana.Udin, dkk.(2011: 261) mengatakan anggaran memadai adalah salah satu syarat penting dalam mengadakan pembinaan PAUD.
Anggaran pun harus akuntabilitas dan citra publik artinya proses penyusunan anggaran diharapkan melalui penjaringan aspirasi masyarakat yang hasilnya digunakan sebagai dasar perumusan arah dan kebijakan umum anggaran.

Menurut anggota DPRD Kabupaten Sintang bagian Pendidikan mengatakan salah satu bentuk tiga pilar kebijakan pemerintah dalam pembinaan PAUD adalah peningkatan mutu dan daya saing. Pemerintah Kabupaten Sintang belum maksimal mewajibkan dan memotivasi masyarakat desa untuk melakukan pembinaan PAUD di desa.Kondisi ini yang menyebabkan masih banyak desa yang tidak melaksanakan PAUD. Peningkatan mutu PAUD di Kabupaten Sintang belum signifikan dan masih rendah karena tenaga pendidik khusus untuk pembinaan PAUD masih kurang. Realita empiris ini mempengaruhi daya saing pendidikan di Kabupaten Sintang masih lemah, ditambah denganparadigma berpikir masyarakat tentang pendidikan bahwa tidak perlu sekolah tinggi karena akankembali bekerja mengelolah tanah.

Kendala dalam melaksanakan tiga pilar kebijakan pemerintah dalam pembinaan PAUD di Kabupaten Sintang.

Menurut Kepala Seksi Pendidikan Anak 


\section{Felix Semaun}

Usia Dini Dinas Pendidikan Kabupaten Sintang mengatakan kendala utama pelaksanaan tiga pilar kebijakan pemerintah dalam pendidikan anak usia dini di Kabupaten Sintang adalah persepsi masyarakat masih rendah terhadap pentingnya pendidikan anak usia dini dan mata pencaharian orang tua. Masyarakat berpandangan bahwa pendidikan anak usia dini tidak menjadi jaminan bahwa anak akan mengalami kemajuan dalam perkembangan kognisi, afektif dan psikomotorik karena meskipun AUD tidak ikut pembinaan PAUD, mereka juga telah mengalami PAUD itu sendiri di rumah dan di lingkungannya. Pembinaan PAUD hanya sekedar untuk bersosialisasi dengan teman pada beberapa jam saja, sementara di rumah dan di lingkungannya selalu bersosialisasi dengan teman-temannya. Selain itu masyarakat desa kebanyakan bermata pencaharian sebagai petani karet dan petani sawit, ada juga yang bekerja di pertambangan emas tanpa ijin Pemerintah. Mereka yang bekerja sebagai penambang emas tanpa ijin khusus dari pemerintah atau illegal bekerja jauh dari kampung. Kondisi inilah yang membuat anak-anak mereka pun mengikuti situasi dan kondisi pekerjaan orang tua. Akhibatnya banyak anak yang tidak mengikuti pembinaan PAUD di desanya.
Menurut anggota DPRD dari daerah pemilihan kecamatan Sintang mengatakan kendala utama penerapan tiga pilar kebijakan pemerintah dalam pendidikan anak usia dini di Kabupaten Sintang adalah kurangnya koordinasi antara pemerintah Kabupaten Sintang melalui Dinas Pendidikan Kabupaten Sintang dengan pemerintah desa. Kurangnya koordinasi ini disebabkan kurangnya komunikasi karena jarak tempuh beberapa desa dengan kota Sintang yang sangat jauh dan akses jalan yang rusak menuju setiap desa sangat berat, serta tidak ada jaringan komunikasi di beberapa desa. Sementara menurut Kepala Dinas Pendidikan Kabupaten Sintang mengatakan kendala yang fundamental adalah kurangnya tenaga pendidik yang memiliki sarjana pendidikan guru PAUD. Selain itu anggaran untuk pembinaan PAUD di setiap desa diatur dan dikelolah oleh pemerintah desa dan masyarakt desa. Kepala desa dan masyarakat desa yang melihat urgensinya pembinaan pendidikan anak usia dini akan berupaya mendirikan lembaga PAUD di desanya dan menyiapkan anggaran bagi perlengkapan sarana-prasarana serta tenaga kependidikan. Hal ini sesuai dengan pendapat Rosadi (2012) mengatakan setiap lembaga pendidikan membutuhkan anggaran dalam meningkatkan kualitas dan kuantitas 


\section{Felix Semaun}

pendidikan. Anggaran pembinaan PAUD di setiap desa penting disiapkan oleh pemerintah desa dan diketahui oleh masyarakat desa.

Upaya mengatasi kendala melaksanakan tiga pilar kebijakan pemerintah dalam pembinaanPAUD di Kabupaten Sintang.

Menurut Kepala Dinas Pendidikan

Kabupaten Sintang mengatakan upaya mengatasi kendala mewujudkan tiga pilar kebijakannya dalam pembinaan pendidikan anak usia dini di Kabupaten Sintang adalah pertama, peningkatan koordinasi dan kerjasama antara Dinas Pendidikan dengan pemerintah desa, dalam hal pendirian lembaga PAUD di setiap desa, kurikulum PAUD, persiapan tenaga pendidik, dan persiapan sarana dan prasarana, kedua, mengajak masyarakat seluruh kabupaten Sintang untuk terlibat mendukung dalam mendirikan lembaga PAUD di setiap desa dan mendukung anak-anak untuk menikmati pendidikan anak usia dini, ketiga, peran serta masyarakat dalam perencanaan, pengelolaan, dan pengawasan kinerja pembinaan PAUD di setiap desa. Herawati, (2015) mengatakan pentingnya kurikulum PAUD dalam mewujudkan tiga pilar kebijakan pemerintah Indonesia dalam pembinaan PAUD. Kurikulum PAUD mensintesakan antara realitas, tantangan dan harapan PAUD di seluruh Indonesia.

Menurut Kepala Seksi Pendidikan Anak Usia Dini Dinas Pendidikan Kabupaten Sintang mengatakan upaya mengatasi kendala pelaksanaan tiga pilar kebijakan pemerintah dalam pembinaan PAUD adalah membuka paradigma berpikir masyarakat dengan cara mengadakan sosialisasi tentang pentingnya pendidikan anak usia dini, mengunjungi masyarakat desa dengan memberikan motivasi tentang perubahan hidup di masa depan dan cita-cita anak-anak usia dini akan tercapai bila melalui pendidikan dan dididik sejak kecil atau dini. Dinas Pendidikan Kabupaten Sintang bekerjasama dengan kampus-kampus yang berada di wilayah Kabupaten Sintang untuk mensosialisasikan tentang urgensi pendidikan di zaman milenial ini karena hanya dengan pendidikan, anak-anak akan meraih impiannya. Anita (2011) mengatakan pola pikir masyarakat yang mau berkembang adalah harus terbuka akan perubahan. Pendidikan adalah jalan menuju perubahan tersebut. Pendidikan anak usia dini adalah peletak dasar bagi perubahan kognisi, afektif dan psikomotorik anak. Masyarakat yang mendukung adanya lembaga PAUD di setiap desa menunjukkan bahwa masyarakat tersebut mengingini anak mereka akan maju dan berkembang. 


\section{Felix Semaun}

\section{SIMPULAN}

Penerapan tiga pilar kebijakan pemerintah dalam pembinaan pendidikan anak usia dini di Kabupaten Sintang sudah berjalan baik namun belum maksimal karena pelbagai macam kendala. Tiga pilar kebijakan pemerintah terrealisasi dalam bentuk adanya perluasan dan pemerataan akses pendidikan anak usia dini di setiap desa, peningkatan mutu dan daya saing dan penguatan tata kelolah, akuntabilitas dan citra publik. Penerapan tiga pilar kebijakan pemerintah di Kabupaten Sintang menemukan kendala seperti kurangnya koordinasi antara Dinas Pendidikan Kabupaten Sintang dengan masyarakat desa, kekurangan tenaga pendidik yang profesional dalam bidangnya, anggaran yang tidak memadai dan sarana prasarana yang kurang. Upaya dalam mengatasi kendala tersebut adalah tingkatkan kerjasama antara Dinas Pendidikan Kabupaten Sintang dengan masyarkat. Kerjasama dengan kampus yang ada di wilayah Kabupaten Sintang untuk membuka program studi Pendidikan Guru PAUD agar ke depannya terakomodir tenaga pendidik PAUD yang belum berijasah sarjana PAUD dan mensosialisasikan tentang urgensi pendidikan di zaman milenial ini karena hanya dengan pendidikan, anak-anak akan meraih impiannya.

\section{SARAN}

Pemerintah melalui Dinas Pendidikan Kabupaten Sintang diharapkan mengembangkan tiga pilar kebijakan pemerintah dalam pembinaan pendidikan anak usia dini di Kabupaten Sintang Para guru pendidikan anak usia dini untuk meningkatkan keprofesionalitasnya dengan mengikuti pelatihan tentang cara dan metode pembelajaran pendidikan anak usia dini. Peneliti selanjutnya agar lebih intens mengkaji tentang tiga pilar kebijakan pemerintah dalam pembinaan pendidikan anak usia dini di Kabupaten Sintang.

\section{DAFTAR RUJUKAN}

Agung, I. 2010. Perluasan Wajib Belajar 12 Tahun : Suatu Pemikiran. Jurnal Penelitian Kebijakan Pendidikan. Hal.119 - 135.

Anita, 2011. Model Pendidikan Anak Usia Dini. Jakarta: Kencana Media Group.

Arikunto, S. 2009. Prosedur Penelitian SuatuPendekatan Praktik. Jakarta: Rineka Cipta.

Departemen Pendidikan dan Kebudayaan. 2007. Undang-undang No.20 Tahun 2003 Tentang Sistem Pendidikan Nasional. (Tidak diterbitkan). Jakarta : Depdiknas.

Depdiknas. 2007. Rencana Strategis Kementrian Pendidikan Nasional 2004-2009. (Tidak diterbitkan). 


\section{Felix Semaun}

Jakarta: Pusat Informasi dan Humas Depdiknas.

Ditjen Dikti. 2006. Gerakan PAUDISASI, Satu Desa Satu PAUD. Jakarta.

Hanafi, T. 2015. Kebijakan Implementasi Kurikulum Pendidikan Anak Usia Dini. Seminar Nasional Kurikulum PAUD. Yogyakarta.

Fadli. 2018. Blogs.htm// Tiga Pilar Pendidikan Nasional/ di akses pada Sabtu, 10 Maret 2018, pukul: 19.40 Wib.

Herawati, N. 2015. Sambutan Ketua Umum PP HIMPAUDI. Seminar Nasional Kurikulum PAUD. Yogyakarta.

Istiqomah. 2016. Tiga Pilar Kebijakan Pemerintah dalam Pembinaan PAUD. Jurnal Ilmiah Tumbuh Kembang Anak. Vol.1 No.2

Latif, dkk. 2014. Orientasi Pendidikan Anak Usia Dini, Teori dan Aplikasi. Jakarta: Kencana Media Group.

Nasution, S. 2009. Metode Research (Penelitian Ilmiah). Jakarta: PT. Bumi Aksara.

Noorlaila, I. 2010. Panduan Lengkap Mengajar PAUD. Yogyakarta: Pinus Book Publisher.

Peraturan Menteri Pendidikan Nasional RI :No 58 Tahun 2009 tentang Standar Pendidikan AUD. (Tidak diterbitkan).

Peraturan Menteri Pendidikan dan Kebudayaan RI No. 137 Tahun 2014 tentang Standar Nasional Pendidikan Anak Usia Dini. (Tidak diterbitkan).
Peraturan Menteri Pendidikan dan Kebudayaan RI No. 146 tahun 2014 tentang Implementasi Kurikulum 2013 PAUD. (Tidak diterbitkan).

Rosadi, D. 2012. Pendidikan Anak Usia Dini dalam Kerangka Otonomi Daerah. Jurnal Ilmiah Anak Usia Dini. Vol.2.No.1.Hal.60-72.

Sugiyono, 2012. Metode Penelitian Pendidikan, Pendekatan Kuantitatif, Kualitatif \& $R \& D$.Bandung: PT. Alfabeta.

-------------. 2014. Metode Penelitian Pendidikan, Pendekatan Kuantitatif Kualitatif $\& R \& D$.Bandung: PT. Alfabeta.

Sujiono. 2009. Konsep Dasar Pendidikan Anak Usia Dini. Jakarta: Indeks Permata Puri Media.

Udin, S. dkk. 2011. Perencanaan Pendidikan Suatu Pendekatan Komprehensif. Bandung: PT Remaja Rosdakarya.

Undang-Undang Republik Indonesia No.20 Tahun 2003 tentang Sistem Pendidikan Nasional.(Tidak diterbitkan).

Undang-Undang Republik Indonesia No.14 Tahun 2005 tentang Guru dan Dosen. (Tidak diterbitkan). 